\title{
When Volcanoes Fall Down-Catastrophic Collapse and Debris Avalanches
}

$D^{-}$ espite their seeming permanence, volcanoes are prone to catastrophic collapse that can affect vast areas in a matter of minutes. Large collapses begin as gigantic landslides that quickly transform to debris avalancheschaotically tumbling masses of rock debris that can sweep downslope at extremely high velocities, inundating areas far beyond the volcano. Rapid burial by the debris avalanches themselves, associated eruptions and lahars (volcanic mudflows), and inundation by tsunamis triggered when avalanches impact bodies of water can all cause widespread devastation to people and property.

A village priest, Tsurumaki-san, was relaxing with friends at a hot spring high on the upper slopes of Bandai volcano in central Japan on the morning of July 15 , 1888. Earthquake swarms had occurred the previous week and Bandai had been steaming as long as people could remember, but the densely forested volcano had not erupted for nearly a century. Suddenly, at about 8 a.m., the ground heaved, and the bathers rushed outside to witness a thunderous explosion and a dark cloud rising into the sky. Tsurumaki-san and his friends fled terrified as the sky turned pitch black, rocks fell around them, and the ground shook, throwing them down. After about an hour, the darkness cleared enough that Tsurumaki-san could flee down the mountain. He survived two more explosions before reaching safety several hours later.

What the priest did not realize was that he had been in a front row seat for one of nature's most dramatic eventsthe catastrophic collapse of a volcano. Bandai volcano had collapsed in a massive landslide that created a gaping U-shaped, mile-wide crater backed by a steep, jagged cliff only about a hundred yards from where the priest had been relaxing earlier that morning. About $1.2 \mathrm{~km}$ cubic kilometers $\left[\mathrm{km}^{3}\right]$ (more than a quarter of a cubic mile $\left[\mathrm{mi}^{3}\right]$ ) of the former summit of the volcano fell away; the massive debris avalanche swept 11 kilometers [km] (nearly 7 miles [mi]) northward and overwhelmed several villages in just minutes.

Despite their seeming permanence, volcanoes can be vulnerable to catastrophic collapse owing to their steep slopes, fractured and complex internal structures, and rocks weakened by long-term chemical reactions. These large collapses, now known to be relatively common, begin as gigantic landslides that quickly transform to debris avalanches - chaotically tumbling masses of rock - that can rapidly travel long distances and inundate areas far beyond the volcano. If sufficient water is available within the collapsing edifice, debris avalanches can transition in part, or entirely, to flows of volcanic rock debris, mud, and water known as lahars, which can sweep even farther than the initial debris avalanches. When Mount Rainier collapsed about 5,600 years ago, a debris-avalanche-generated lahar reached as far as Puget Sound.

Surprisingly this catastrophic volcanic hazard has received little attention until relatively recently. The typically hilly (or hummocky) deposits of volcanic debris located far beyond the flanks of volcanoes had long puzzled geologists. In the years prior to the 1980 eruption of Mount St. Helens, Japanese scientists began to recognize the similarity of hilly deposits at Bandai and other volcanoes to nonvolcanic landslides and differentiate them from other types of volcanic deposits. The 1980 eruption of Mount St. Helens afforded geologists their first opportunity to observe the collapse of a volcano and document the emplacement of a debris-avalanche deposit. These observations fundamentally changed the way volcanologists thought

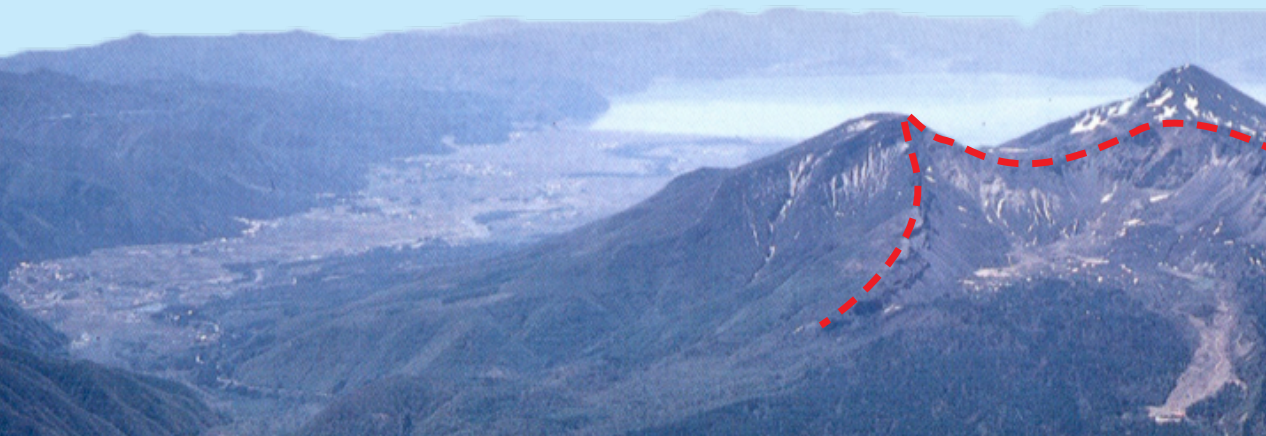
1888 , generating a massive, high-velocity debris avalanche that covered the entire area below the north side of the volcano, burying villages and causing 457 fatalities. The debris avalanche left thick piles of hilly S. Department of the interior a 3. volcanic debris that blocked drainages to form lakes of various sizes. The collapse scarp is shown by the red dashed line. Image used with permission from Fukushima Minpo News. 


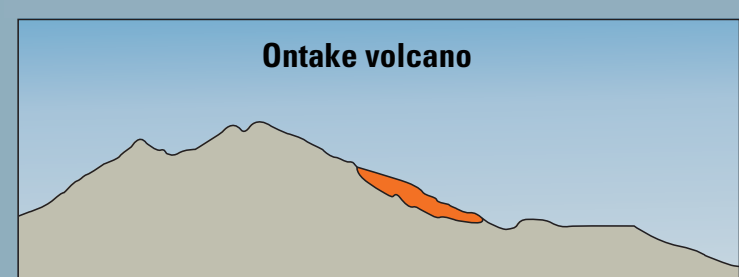

\section{B}

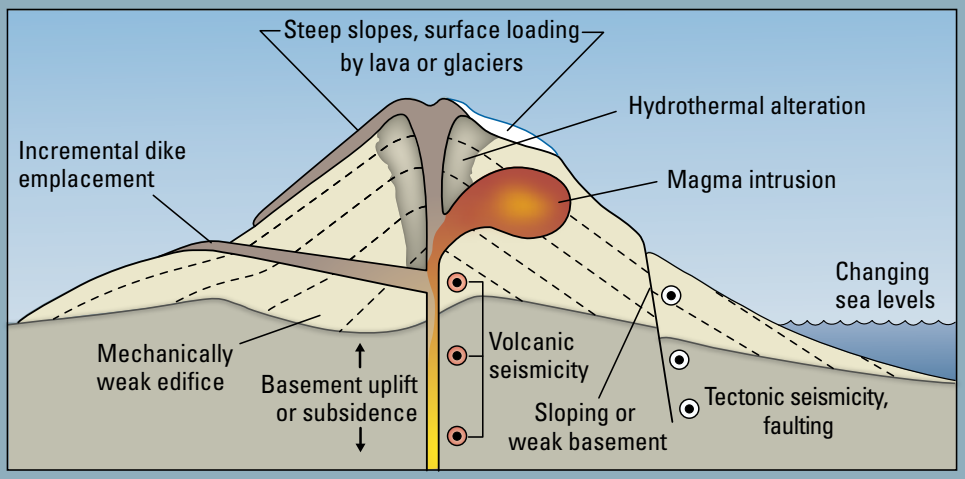

C

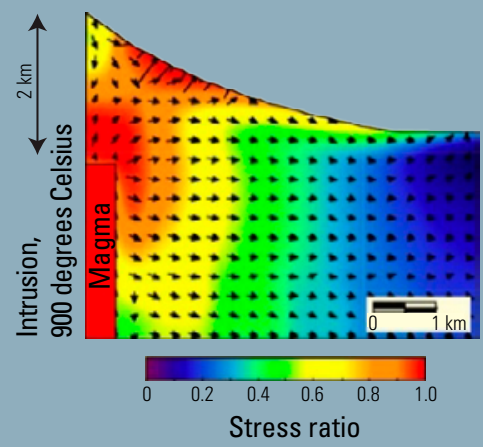

(A) Cross-section of collapses from two volcanoes in Japan, where the first (Ontake) is a relatively shallow collapse similar to those occurring at nonvolcanic mountains, and the second (Bandai) shows the type of deep collapse found at volcanoes (Reid, 2004). (B) Cross-section of a volcano showing a few of the many volcanic and nonvolcanic factors promoting instability (modified from McGuire [1996] and Siebert [2002]).

(C) Model of internal stresses within a cross section of a volcano, with the conduit at the left. Heating from intrusion of hot magma increases fluid pressures within pores of the rock. This causes higher stresses (warm colors) and can lead to collapse. Figure modified from Reid (2004). km, kilometers. about the behavior of volcanoes and led to the recognition that debris avalanches are relatively common and extremely devastating. Some of these avalanches can be astonishingly large, such as those from Meru volcano in Tanzania and Barú volcano in Panama, each of which inundated about 1,200 square kilometers (more than 450 square miles), an area roughly a third of the size of the state of Rhode Island.

\section{What Causes Volcanoes to Collapse?}

The growth and evolution of a volcanic edifice can predispose it to collapse, and a variety of dynamic processes can trigger collapse. The steep flanks of volcanoes can spawn relatively shallow and small landslides similar to those at other large, nonvolcanic mountains. These shallow landslides may be triggered by increased groundwater pressures from rainfall or snowmelt or from strong earthquake shaking.

Much deeper landslides typically occur only at volcanoes and generate unusually large debris avalanches. Many processes, both volcanic and nonvolcanic, may make an edifice, or parts of it, more susceptible to collapse. Volcanic processes include the circulation of hot, acidic fluids within a volcano over thousands of years, which can alter volcanic rocks to weak clays (hydrothermal alteration). Other dynamic processes, operating over days to months, can modify stresses in the core of a volcano and trigger deep and rapid collapse. Shallow magma intrusion may directly push on and steepen a volcano's flanks, as well as fracture and weaken rocks within the edifice. In addition, heat from a shallow magma intrusion can pressurize pore fluids in a volcano and create a large collapse.

Contemporary observations of historical deep-seated volcano collapses reveal that

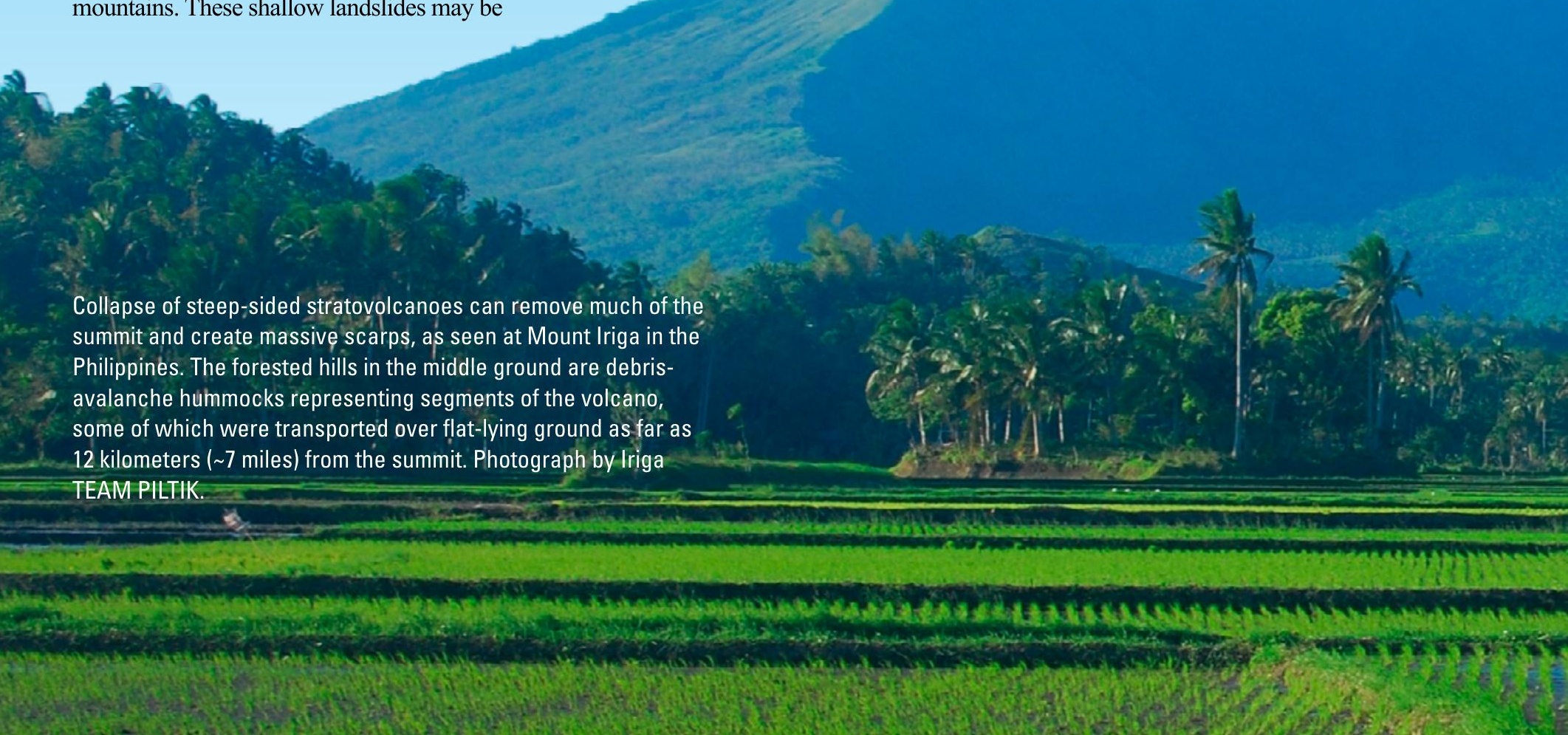




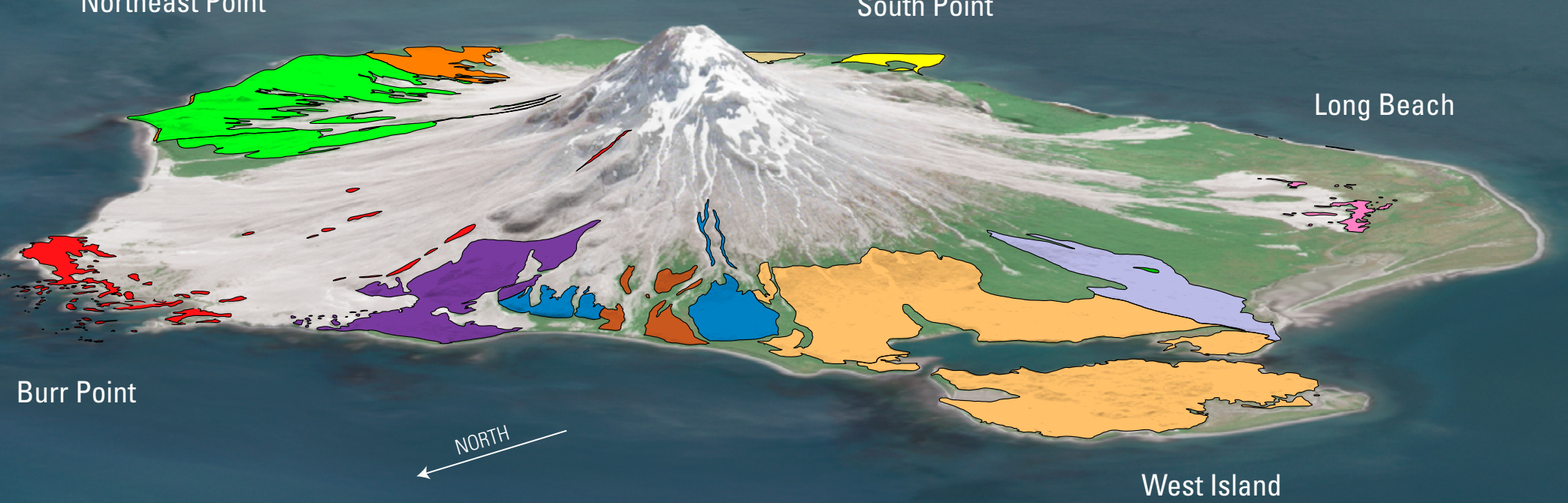

The steep-sided Augustine lava-dome complex in Cook Inlet of Alaska is ringed by deposits of multiple debris avalanches. Augustine volcano has collapsed a dozen times or more in the past 2,500 years and has the highest known rate of edifice collapse of any volcano. The debris-avalanche deposits (colored) in this image extend out to sea on all sides and are partly covered by deposits of younger eruptions (gray) closer to the volcano. The impact of the debris sweeping into the ocean may have produced tsunamis, such as the 1883 Cook Inlet tsunami caused by the Burr Point collapse. Selected deposits are named, with the Burr Point deposit (in red) being the youngest. Base map from July 3, 2018, Landsat 8 image is overlain by debris-avalanche deposits mapped by Waitt and Begét (2009).

volcano-related processes contributed to their failures. At Mount St. Helens and Bezymianny (Russia) volcanoes, shallow magma intrusion immediately preceded the collapse. At Bandai volcano, magmatically heated water generated eruptions of pressurized steam and ash that preceded collapse without magma reaching the surface. In all of these cases, an initial large failure propagated quickly into the weakened cores of each volcano.

\section{What Kinds of Volcanoes Collapse?}

Steep-sided stratovolcanoes are most prone to deep failure and can produce massive debris avalanches with volumes of tens of cubic kilometers. When a volcano suffers a major collapse, large sections of the volcano's core are removed, greatly reducing the height of the volcano and leaving a large, often U-shaped, scar or scarp (cliff) open in the direction of avalanche travel. These scarps typically range from $<1$ to about $5 \mathrm{~km}$ (about 0.5 to about $3 \mathrm{mi}$ ) in width but are often partly or totally obscured as new eruptions reconstruct the volcano by filling the collapsed crater. Not all collapses of stratovolcanoes involve the central conduit and core of the volcano. Smaller flank collapses at stratovolcanoes are much more common, but some can be sizeable nonetheless, sometimes exceeding $0.1 \mathrm{~km}^{3}\left(\sim 0.025 \mathrm{mi}^{3}\right)$.

Other types of volcanic structures can also produce debris avalanches. Lava-dome complexes - such as those at Shiveluch in Kamchatka (Russia) and Augustine in Alaska's Cook Inlet - are often even steeper than stratovolcanoes and are prone to collapse. Debris avalanches can occur at calderas (volcanic depressions) when major parts of volcanoes collapse during an eruption or from failure of caldera walls long after the eruption.

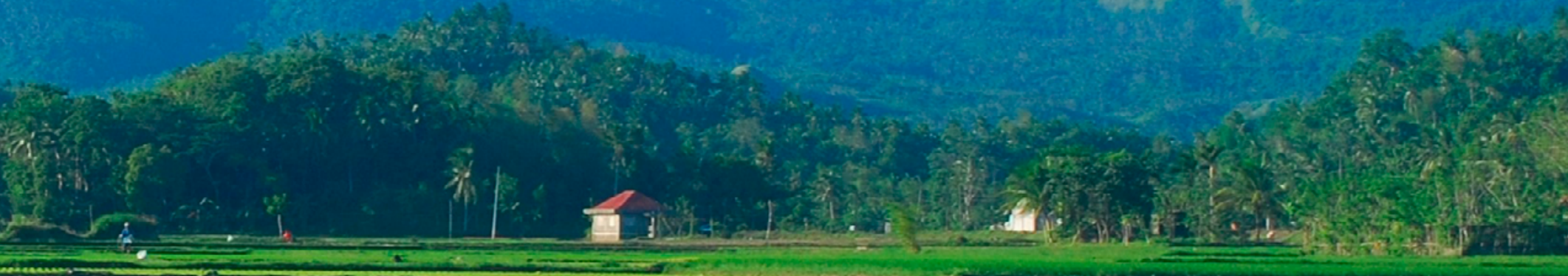




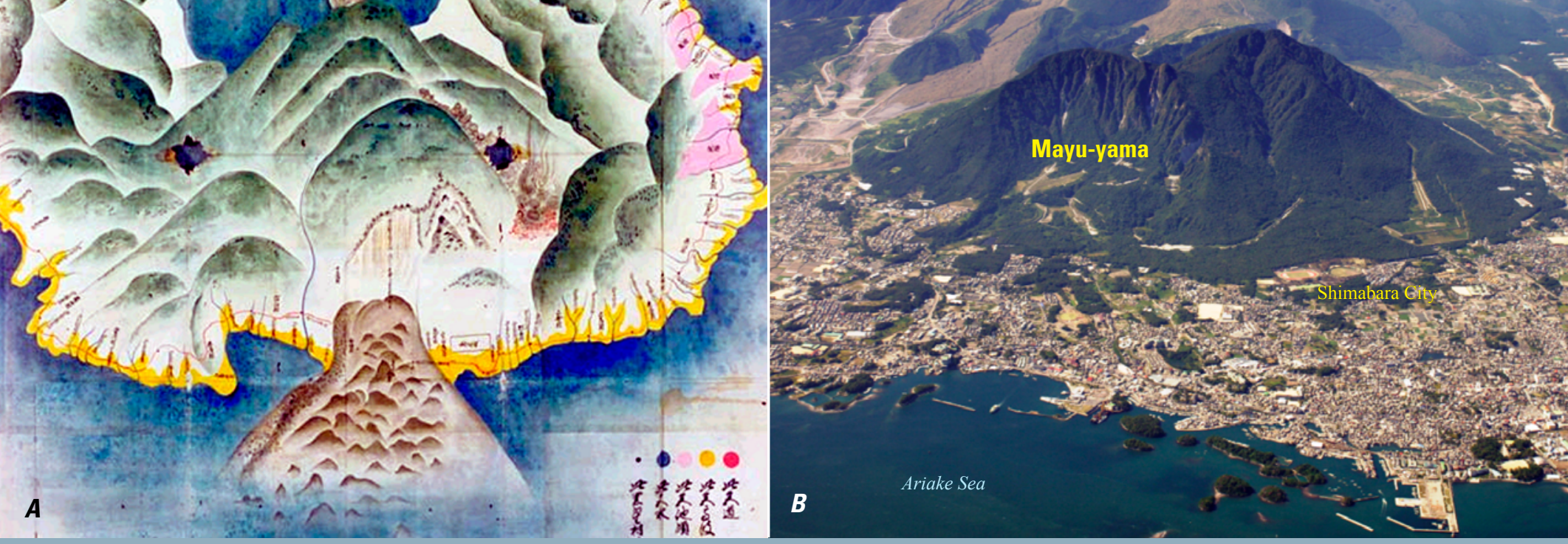

A dramatic map prepared after the 1792 catastrophe at Unzen volcano in Japan (A) shows hummocky avalanche debris from collapse of Mayu-yama lava dome that swept into the sea, producing a tsunami with coastal wave run-up (shown in yellow) that scoured the Shimabara Peninsula shoreline. Image used with permission of Tokiwa Museum of Historical Materials, Shimabara. (B) An aerial photograph shows Mayu-yama lava dome with forested debris-avalanche hummocks scattered downslope within Shimabara City and forming islands offshore. Image from Nagasaki Prefecture (www.visit-nagasaki.com).

Structural failure can also occur on volcanoes with much gentler slopes, as demonstrated by multiple failures of massive oceanic shield volcanoes in the Hawaiian Islands and many other volcanic island chains. Repeated intrusions of magma along lengthy, inherently weak rift zones can wedge them apart and eventually cause an unsupported seaward flank of the volcano constructed over weak oceanic sediments to slide away. This can produce monumental-scale submarine debris avalanches more than 1,000 times larger than the one at Mount St. Helens in 1980. Geologists have documented landslides on the scale of entire volcanic fields in the Absaroka Range near Yellowstone in Wyoming and in the Markagunt Plateau of Utah that rival the size of those from oceanic shield volcanoes.

Fortunately, collapse on such a massive scale is very infrequent. Although both submarine and, less frequently, land collapses have occurred in the distant geologic past, no such collapses are known to have occurred in more recent time. However, conditions leading to collapse remain and future events cannot be ruled out.

\section{How Often do Volcanoes Collapse?}

Edifice collapse and debris-avalanche formation, once thought to be extremely rare, is now known to be a relatively common occurrence at many, but not all, volcanoes. In some volcanic regions, such as the Cascade Range and Kamchatka Peninsula (Russia), the majority of major stratovolcanoes have collapsed at least once during their lifespan. Furthermore, as geologists look more closely at ancient avalanche deposits, it is apparent that some volcanoes collapse and reconstruct themselves multiple times. Volcanoes such as Colima in Mexico, Taranaki (Egmont) in New Zealand, and Augustine in Alaska have each collapsed 10 or more times, forming broad aprons of sometimes overlapping debrisavalanche deposits that surround the volcanoes. Along the entire volcanic arcs of Japan and Kamchatka, collapse rates have averaged about one per century. On a global scale, during the past 500 years debris avalanches larger than $0.1 \mathrm{~km}^{3}\left(\sim 0.025 \mathrm{mi}^{3}\right)$ in volume have occurred about five times a century.

\section{What are the Hazards Associated with Debris Avalanches?}

Debris avalanches can travel at very high velocities ( $>100$ meters per second at Mount St. Helens [about 225 miles per hour]) and devastate broad areas adjacent to volcanoes in a matter of minutes. Associated magmatic eruptions may include lateral blasts and other types of pyroclastic density currents (hot dry flows of volcanic rock debris and gas). Lahars can form at different times throughout an avalanche event, during the avalanche or hours after it stops. Lakes that form when debris avalanches block drainages can overflow many months to years later and fail catastrophically, generating lahars.

In historical time, debris-avalancheinduced tsunamis have caused many more deaths than the debris avalanches themselves or the eruptions associated with them. In 1888, the collapse of Ritter Island, a small volcano off the northern coast of Papua New
Guinea, launched the largest debris avalanche known in historical time. The resulting tsunami traveled more than $700 \mathrm{~km}(>400 \mathrm{mi})$, ran up shorelines as high as 15 meters [m] (50 feet [ft]) and caused an estimated 3,000 fatalities. In 1792, Mayu-yama lava dome at Unzen volcano on the southern Japanese island of Kyushu collapsed, caused a debris avalanche that swept into the Ariake Sea, and generated a catastrophic tsunami. A tsunami with three wave crests swept $70 \mathrm{~km}$ (>40 mi) of the Shimabara Peninsula coastline and traveled across the bay, washing away nearly 6,000 houses, 1,600 fishing boats, and about 14,500 persons in Japan's worst volcanic disaster. More recently, a tsunami produced by the collapse of Indonesia's Anak Krakatau volcano on December 22, 2018, caused more than 400 fatalities.

Although debris avalanches are relatively infrequent, they present one of the most devastating volcanic hazards. Increasing population densities near volcanoes have placed large numbers of people within reach of debris avalanches, associated lahars, or, in coastal areas, debris-avalanche-derived tsunamis.

Debris avalanches are usually associated with eruptive activity or volcanic unrest. Although substantial progress has been made in the identification of factors that contribute to edifice instability, the generation of hazard maps that model their likely extent, and the implementation of monitoring techniques to detect ground movements, predicting when debris avalanches will occur remains difficult. Hazard maps and volcano monitoring, if available and heeded, can reduce - but not eliminate-risk. 
At 8:32 a.m. on May 18, 1980, Mount St. Helens in Washington, which had been erupting intermittently since March 27, collapsed in a massive landslide that was observed by geologists and onlookers who had positioned themselves around the volcano to watch and photograph its eruptions. The landslide and resulting debris avalanche uncorked a body of magma that had slowly intruded into the upper part of the volcano, causing its glacier-covered north flank to fracture and bulge ominously. The sudden removal of rock overlying this high-temperature magma body depressurized it, producing a violent lateral blast, a hot mixture of rock fragments and gas that initially traveled at supersonic velocities and swept out over a broad arc north of the volcano, blowing down towering conifers like matchsticks.

The avalanche slammed into Spirit Lake, displacing the water and causing a tsunami-like wave that swept as high as $260 \mathrm{~m}(850 \mathrm{ft})$ above the lakeshore, stripping the mountainsides of soil and trees, and leaving a massive raft of logs that remain floating on the surface of the lake to this day. The rapidly moving avalanche had sufficient momentum to overtop the 380-m (1,250 ft)-high Johnston Ridge (named for U.S. Geological Survey volcanologist David Johnston, who observed the initial moments of the eruption from his observation station near the crest of the ridge before he was overtaken by the lateral blast). Most of the debris avalanche was deflected by Johnston Ridge westward down the North Fork Toutle River, and within about 10 minutes ultimately reached $26 \mathrm{~km}(16 \mathrm{mi})$ from the volcano's former summit, filling the valley to an average depth of $45 \mathrm{~m}$ ( $\sim 150 \mathrm{ft})$ with hummocky volcanic debris.

Detailed studies of the deposits of the May 18 eruption revealed a close match between the volume of the debrisavalanche deposit and the missing portion of the volcano's summit. Thus, the volcano did not "blow off its top," as is often incorrectly stated: the landslide and avalanche, rather than the lateral blast, were primarily responsible for the destruction of the volcano's summit and the formation of the massive breached crater whose floor lay an astonishing 1,100 m (3,600 ft) below the former summit.

The 1980 Mount St. Helens eruption was instrumental in changing scientists' understanding of edifice collapse and its consequences. Work since then has demonstrated that this is a much more common volcanic hazard than was previously realized and that it can occur under a wide variety of conditions. The devastating lateral blast at Mount St. Helens occurred when magma rose high into the edifice prior to collapse. In most other cases of edifice collapse, magma is farther beneath the summit and more typical vertical explosions occur. When magma lies even deeper, magma-free steam-driven explosions occur (such as at Bandai in 1888). Collapse with debris-avalanche formation can also occur in the absence of eruptive activity.

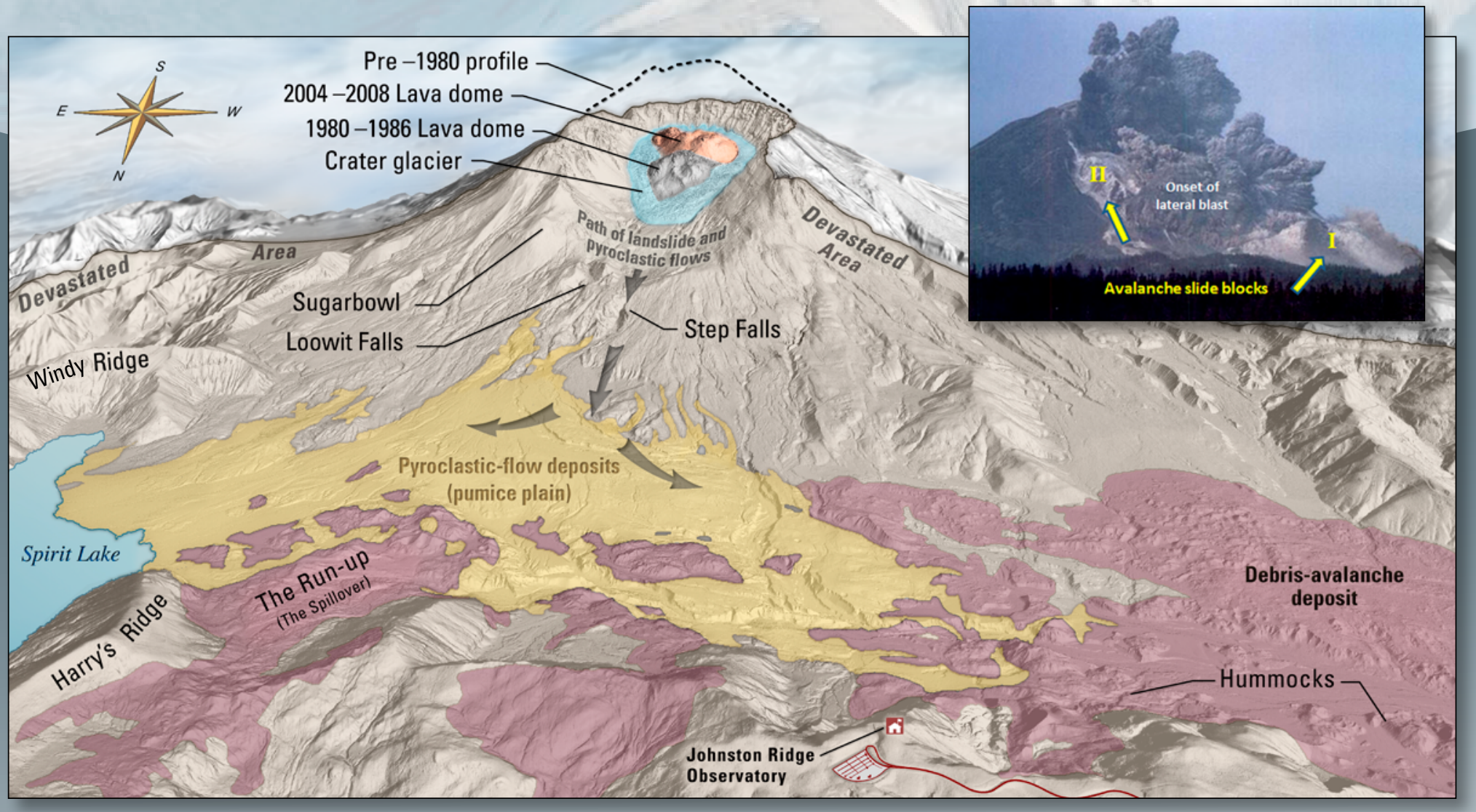

The events of May 18, 1980, dramatically changed the landscape at Mount St. Helens and created one of Earth's largest historical debris-avalanches (shown in purple color). The crater left by the collapse is 1.9 kilometers (1.2 miles) wide from east to west. The inset photograph shows a view from the northeast of the first two landslide blocks of rock and ice debris at Mount St. Helens, shortly after the start of the avalanche. The lateral blast that swept the "Devastated Area" began as slide block II collided with the area of explosions produced by sudden depressurization of the magma body, which were caused by removal of slide block I. Image modified from Dzurisin and others (2013); inset image modified from photograph by Gary Rosenquist, copyright 1980, used with permission. 


\section{How are Debris-avalanche Deposits Recognized?}

Geologists use both surface features and internal textures of volcanic deposits to distinguish debris avalanches from other types of deposits. A common characteristic is the presence of numerous hills or mounds, often referred to as hummocks, that represent parts of the volcanic edifice transported as relatively intact blocks. Hummocks typically range in size from a few feet to several hundred feet high, with intervening enclosed depressions that are commonly filled by small ponds or lakes. Hummocks are transported within more thoroughly mixed material, which may form large areas of flat terrain.

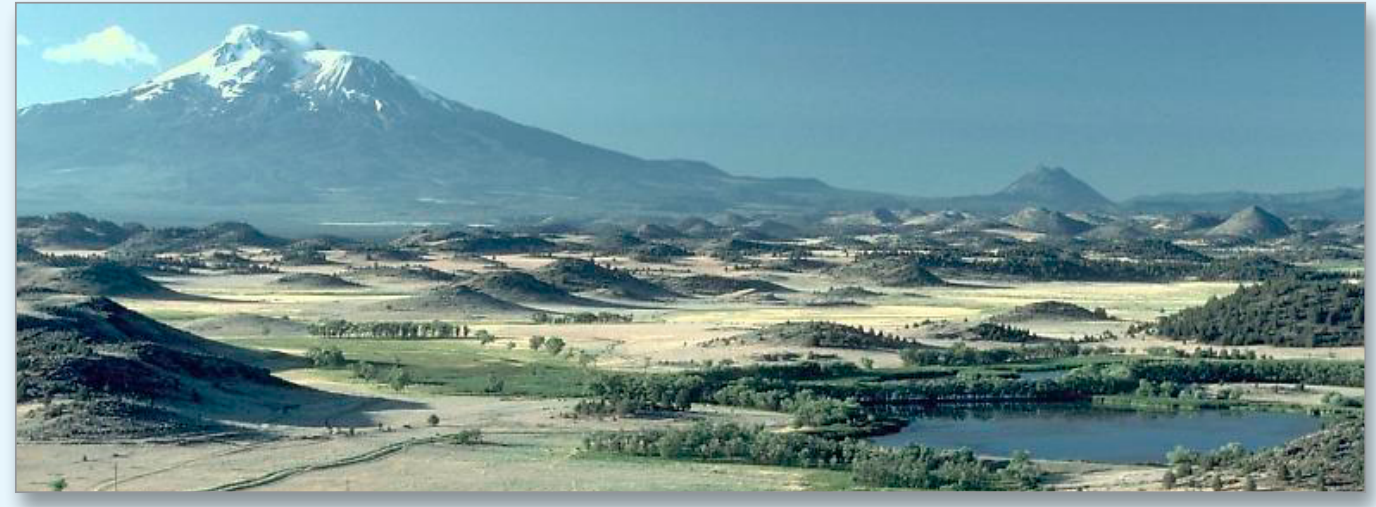

The many hummocks (small hills) below Mount Shasta in California are part of a massive debris avalanche that traveled more than 70 kilometers ( 40 miles) from the volcano between about 360,000 and 300,000 years ago. U.S. Geological Survey scientists working on the 1980 Mount St. Helens debris avalanche recognized the origin of these long-puzzling hills while driving across the avalanche deposit on the Interstate highway. Photograph by Steven Brantley, U.S. Geological Survey.

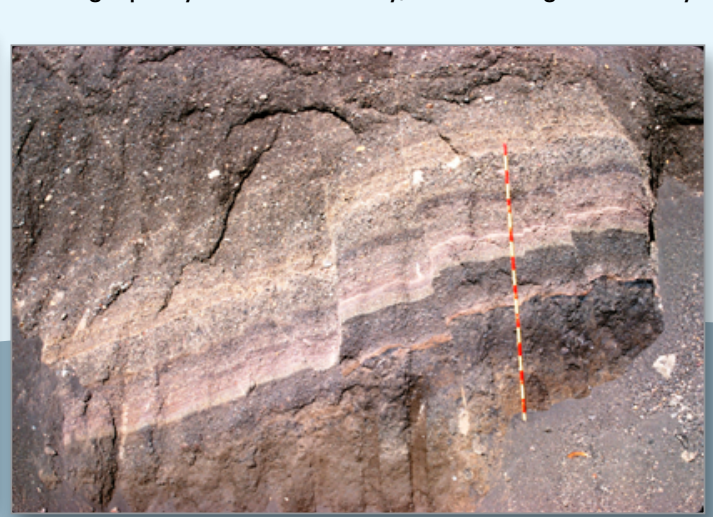

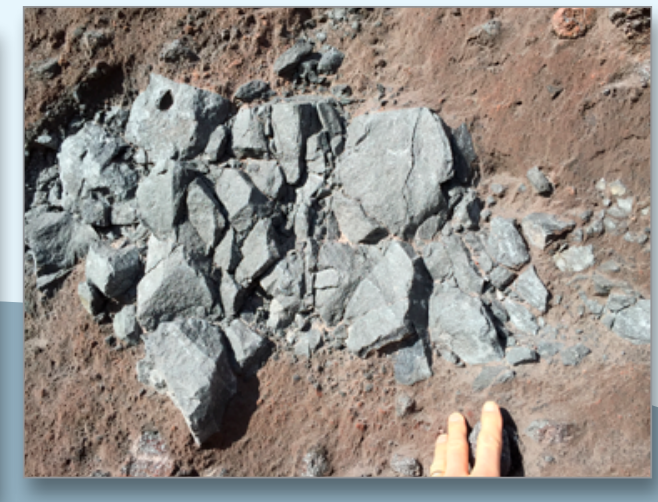

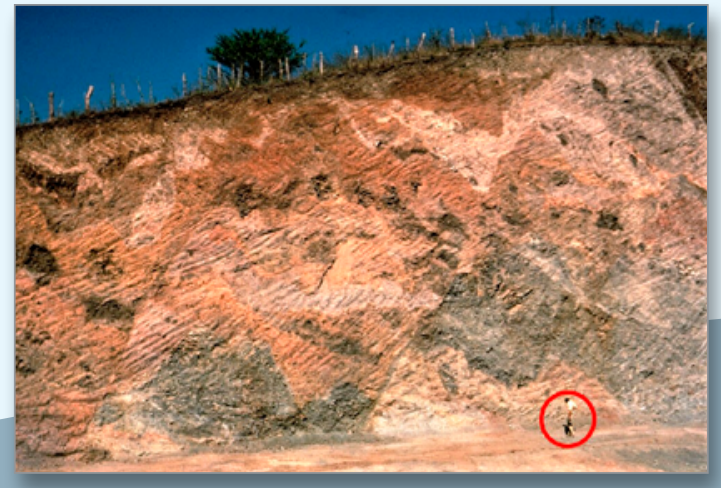

Debris-avalanche deposits contain sections of the volcano that are transported relatively intact for long distances, which can produce a pronounced color mottling that differs from the more monochromatic hues of lahar deposits (in which material has been thoroughly mixed). Lava flow segments and fragmental material (left) moved 30 kilometers (km) ( 20 miles [mi]) from the Fuego-Acatenango complex in Guatemala (geologist circled for scale). Pastel outcrop hues often provide evidence of weakening of the pre-collapse volcano by extensive hydrothermal alteration. Delicate features such as intact bedded ashfall deposits (center) traveled $25 \mathrm{~km}$ (16 mi) in a debris avalanche from El Salvador's Santa Ana volcano (scale is 2 meters [6.5 feet] high). Blocks may be shattered without being dispersed (right), forming jigsaw fractures as shown here within the 1980 debris-avalanche deposit at Mount St. Helens. Left-side and center photographs by Lee Siebert, Smithsonian Institution; right-side photograph by Thomas Pierson, U.S. Geological Survey.

\section{References}

Dzurisin, D., Driedger, C.L., and Faust, L.M., 2013, Mount St. Helens, 1980 to nowWhat's going on?: U.S. Geological Survey Fact Sheet 2013-3014, v. 1.1, 6 p. and videos.

Glicken, H., 1996, Rockslide-debris avalanche of May 18, 1980, Mount St. Helens volcano, Washington: U.S. Geological Survey OpenFile Report 96-677, 90 p., 5 pl.

McGuire, W.J., 1996, Volcano instability-A review of contemporary themes, in McGuire, W.J., Jones, A.P., and Neuberg, J., eds., Volcano instability on the Earth and other planets: Geological Society [London] Special Publications, v. 110, p. 1-23.
Reid, M.E., 2004, Massive collapse of volcano edifices triggered by hydrothermal pressurization: Geology, v. 32, no. 5, p. $373-376$.

Siebert, L., 2002, Landslides resulting from structural collapse of volcanoes, in Evans, S.G., and DeGraff, J.V., eds., Catastrophic landslides - Effects, occurrence, and mechanisms: Geological Society of America Reviews in Engineering Geology, v. XV, p. 209-235.

van Wyk de Vries, B., and Davies, T., 2015, Landslides, debris avalanches, and volcanic gravitational deformation, chap. 38 of Sigurdsson, H., ed., The encyclopedia of volcanoes ( $2 \mathrm{~d}$ ed.): Amsterdam, Elsevier, p. 665-685.
Voight, B., and Elsworth, D., 1997, Failure of volcano slopes: Geotechnique, v. 47, no. 1, p. 1-31.

Waitt, R.B., and Begét, J.E., 2009, Volcanic processes and geology of Augustine volcano, Alaska: U.S. Geological Survey Professional Paper 1762, 78 p., 2 pl., scale 1:25,000.

Lee Siebert, Mark E. Reid, James W. Vallance, and Thomas C. Pierson

Edited by Katherine Jacques

Layout and design by Cory D. Hurd and Geraldine Dang

Banner image and transparency from USGS

For more information, contact: U.S. Geological Survey Volcano Hazards Program 12201 Sunrise Valley Dr., MS 905, Reston, VA 20192 https://volcanoes.usgs.gov/ 